\title{
O CONTEXTO DAS POLÍTICAS DE DESENVOLVIMENTO RURAL E LOCAL: LIÇÕES DO CASO FRANCÊS
}

\author{
LUÍS MORENO $^{1}$
}

Das publicações sobre desenvolvimento rural, algumas importam como referência do ponto de vista do "enquadramento histórico e institucional" desse processo. É o caso de uma obra de Paul HouÉE ${ }^{2}$, com segunda edição revista e aumentada em 1996 (alvo desta recensão) mas a mesma responsabilidade editorial de 1989. Com uma orientação histórico-sociológica, trata-se de um trabalho que incide especificamente sobre a França, embora também sobre a influência da Comunidade Europeia através das suas políticas que se repercutem no desenvolvimento e ordenamento rural, estas aliás inspiradas em grande medida nos êxitos da política interna francesa.

O livro encontra-se solidamente estruturado: divide-se em quatro partes, dez capítulos e mais de uma centena de pontos agrupados sob títulos sugestivos e ilustrativos. Este aspecto não deixa de traduzir a maturação e o comprometimento inerentes ao longo percurso do autor como investigador e activista do desenvolvimento local, ligado tanto a actividades directivas nas áreas do planeamento como às de dinâmica associativa e política. De forma coerente, a nota biográfica da contracapa anuncia que a obra «carrega consigo o cunho de uma investigação-acção de desenvolvimento territorial, numa dinâmica que vai constantemente "da aldeia ao planeta e do planeta à aldeia"» (trad. livre).

$\mathrm{Na}$ sua primeira edição, a obra consistia numa tentativa de síntese sobre: as condições do mundo rural francês desde 1945 a 1989 (primeira parte); as políticas num período de expansão e de confiança generalizada num progresso sem limites, ou seja, de 1945 a 1974 (segunda parte); as políticas num contexto de incerteza, de crise económica, de interrogação social e de apelo às contribuições regionais e locais (terceira parte).

\footnotetext{
1 Assistente da Faculdade de Letras, Universidade de Lisboa. Investigador do Centro de Estudos Geográficos da Universidade de Lisboa. Centro de Estudos Geográficos, Faculdade de Letras, Cidade Universitária, 1699 LISBOA Codex. Tel. (01) 79402 18; fax: (01) 79386 90; e-mail: ceg@mail.telepac.pt

2 HoueE, P. (1989) - Les politiques de développement rural: des années de croissance au temps d'incertitude, Paris, INRA-Economica.
} 
Nesta segunda edição, a primeira parte é remodelada de forma a integrar numerosos dados e a contemplar as mudanças aceleradas do período de 1989-1995. No que resta, à excepção de pequenas alterações de pormenor nas partes segunda e terceira, conta-se principalmente com o acréscimo de uma «Quarta parte» sobre este período da "história" mais recente, apropriadamente intitulado «Gerir a diversidade». Apesar dos riscos da «história imediata», o autor argumenta com a necessidade de fornecer uma síntese provisória, a fim de permitir oferecer "um quadro de referência aos actores do desenvolvimento, um instrumento pedagógico para uso de estudantes e praticantes (...)" (p. 17).

Na primeira parte do volume, é patente um esforço de caracterização diacrónica e abrangente da tríade "sociedade, economia, território", ilustrando a inserção da plurifacetada ruralidade francesa na dinâmica de modernização, concentração e especialização selectiva após a segunda guerra mundial. A «resistência do rural»e a decorrente renovação ou «renascimento rural» (adopção da expressão marcante de Bernard Kayser) traduz o que reconhece como um movimento simultâneo de recomposição e integração das sociedades rurais, como um sintoma de «modernidade» associado à perda relativa da função agrícola - a par do crescimento da pluriactividade e da terciarização da economia - e a um certo ganho em poder de representação.

A partir daqui a obra incide concretamente na descrição e problematização das políticas de desenvolvimento agrícola e rural - desde a tecnocrática e centralizada, de modernização agrícola, até àquelas sucessivamente mais descentralizadas, (com)participadas e abrangentes (em particular após a implementação da DATAR) - em função das conjunturas sócio-económicas e das relações de poder em presença. O autor privilegia a dimensão endógena como geradora de múltiplos jogos de forças, ao descrever o papel "indutor" de cerca de quatro dezenas de agentes (não necessariamente em actividade simultânea; desde a $2^{\text {a }}$. Guerra Mundial alguns tiveram mesmo existência efémera ou bem delimitada), entre sindicatos, organismos estatais, associações, grupos de estudos, para além de várias colectividades locais.

Por outro lado, é interessante notar o papel antecedente da experiência francesa (embora não só) na adopção comunitária (aquando da reforma dos fundos estruturais) do princípio da subsidiariedade e dos vários aspectos que ele implica, em coerência com um sistema de planeamento que apela ao aprofundamento da democracia. Assume-se declaradamente a indissociabilidade destas políticas das dinâmicas e do controlo político do ordenamento rural e do ordenamento mais geral do território, face ao contexto de uma economia globalizada em crise estrutural (que incorpora a problemática ambiental). 